\title{
Serbian Dental Institutions Top Cited Research (1996-2018)
}

\author{
Jelena Jaćimović \\ University of Belgrade, School of Dental Medicine, Central Library, Belgrade, Serbia
}

\begin{abstract}
SUMMARY
Introduction Citation analysis, as one of the best-known bibliometric approaches, is widely used in the evaluation of research output and assessment of research performance and impact. The purpose of this study was to identify the top cited articles published by researchers affiliated to Serbian dental institutions and to analyze their characteristics in order to describe cooperation at individual and institutional, as well as at national and international level.

Material and Methods Articles that cited the most 2018 publication in the Web of Science were assessed. The analyzed aspects covered distribution of annual production, annual citations, journals, categories, countries, institutions, authors, research focuses and trends by author keywords and KeyWords Plus.

Results The top cited papers were published in 60 journals from 1997 to 2016, with the mean number of 45.08 citations per article. These papers were co-authored by 449 authors, responsible for 726 authorships, affiliated to 149 institutions from 41 countries. Among the overall number of authors, 238 were from Serbia, while 211 were affiliated with international institutions. The most productive institutions were the University of Belgrade and Military Medical Academy from Serbia, whilst the international contributing institutions were primarily from the USA, England, and Italy. Conclusion The present study presented useful insight into the most influential Serbian dental institutions research, revealing the most productive actors and multidisciplinary nature of the research contribution.
\end{abstract}

Keywords: bibliometrics; citation analysis; Serbia; Dentistry, Oral Surgery and Medicine

\section{INTRODUCTION}

Bibliometrics has been applied in various forms for studying the structure and process of scholarly communication [1]. This powerful set of methods and measures has been used as a practical tool that can provide the knowledge of scholarly communicative behavior through the overall production of scientific literature on a macro or a micro level of analysis. Bibliometric indicators offer quantitative perspective of scientific activities and interactions, and can be used in combination with other indicators. Measuring ideas, as the main products of science, is difficult and each indicator has its advantages and limitations that must be taken into consideration. The first bibliometric indicator count of published papers - reflects scientific output. Paper counts provide an initial and simplified measure of the quantity of work that a researcher, a department, an institution, a national or international scientific team, a country produced. Citations, as one of the best-known bibliometric indicators, may be considered as a measure of the cited articles' impact and reflection of their utility, recognized by the scientific community. The number of co-authored papers is an indicator of cooperative research achieved at individual or institutional, as well as national or international level. With the development of various networked information technologies, highly evolved quantitative and qualitative bibliometric methods emerged.

The number of times an individual paper is cited still presents the primary indicator, often linked to the out- standing research attributes. Along with the increasing attention directed to research evaluation, the number of bibliometric studies, dealing with the highly cited papers in various scientific disciplines, has been growing [2-5]. Highly cited papers concept has been described in different fields and named as the most cited papers, classic publications, top cited articles etc. Research articles, classified as classic publications or top cited, were investigated in a variety of disciplines, including oral cancer $[6,7,8]$, maxillofacial surgery $[9,10]$, implant dentistry $[3,11,12]$, endodontics [13], orthodontics [14,15], or periodontology $[16,17]$. Most of the conducted bibliometric studies analyzed the most cited articles retrieved from the Web of Science database by Clarivate Analytics, which has been widely recognized as the most comprehensive source of the highest impact journals worldwide. Serbian dental academic research and clinical institutions are characterized with long and prosperous tradition of scientific production. Identification of the articles that have influenced the most, as measured by citation count, may provide the starting point for the description of the Serbian dental scientific communication and its world-class research.

The purpose of this study was to identify, using the established method in evaluative bibliometrics, the top cited articles published by authors affiliated to Serbian dental institutions or departments, and analyze their characteristics in order to describe the cooperation at individual and institutional level, as well as national and international level. This analysis covered annual production from 1996 to 2018 
through the Web of Science database, including citations, journals, the Web of Science categories, countries, institutions, authorship, author keywords, and KeyWords Plus.

\section{MATERIAL AND METHODS}

The top cited articles authored by researchers affiliated to Serbian dental departments or institutions were retrieved from Clarivate Analytics' Web of Science and used for further analysis. The search was performed with the Web of Science Core Collection Citation Indexes that included Science Citation Index Expanded (SCI-EXPANDED), Social Sciences Citation Index (SSCI), Arts \& Humanities Citation Index (A\&HCI), Conference Proceedings Citation IndexScience (CPCI-S), Conference Proceedings Citation IndexSocial Science \& Humanities (CPCI-SSH) and Emerging Sources Citation Index (ESCI). Web of Science does not cover the majority of dental conferences, besides those whose proceedings papers were published in special issues of some referenced journals. The following search strategy produced a sample of documents used for further analysis:

ADDRESS: ((srb* OR serb*) SAME (dent* OR stom* OR maxill* OR oral OR prosthod ${ }^{\star}$ OR orthodon ${ }^{\star}$ OR en$\left.\operatorname{dod}^{\star} \operatorname{OR}_{\text {periodon }}{ }^{\star}\right)$ )

Indexes $=$ SCI-EXPANDED, SSCI, A\&HCI, CPCI-S, CPCI-SSH, ESCI

Timespan $=1996-2018$

All articles that resulted with this search procedure were included without restrictions regarding the article type. In the first step total of 1,451 articles published by authors affiliated to Serbian dental institutions or departments were obtained. Articles were sorted by option "times cited" in the descending order from the highest to the lowest cited article (all articles were ranked by the number of citations listed in the Web of Science). Thereafter, the 100 top cited articles published between 1996 and 2018 were identified. Since the articles ranked 101 and 102 received the same citation count as the last two articles, they were also included in the study. Out of 1451 articles, 462 have never been cited in the Web of Science database, while 989 articles had at least one citation. For the top 102 articles RIS format file was generated and imported to BibExcel [18] in order to perform bibliometric analysis. BibExcel is a software designed to assist in analyzing bibliographic data, or any data of a textual nature formatted in a similar manner. It enables work with large datasets and it is compatible with various software applications aimed for network analysis. For the analysis of bibliometric data and their visualization in networks VOSviewer was used [19].

The following variables were recorded for each article and included in the analysis: author information (first author, co-author), article title, article type, cited references, country and institution of origin, keywords, KeyWords Plus, number of citations (Web of Science Core Collection), journal and its published year, the Web of Science category and Research Area. Each document was considered with respect to all authors' institutions and countries, and not only by the first or corresponding author. Records were manually refined and normalized in order to unify terms and remove typographical, transcription and/or indexing errors. Data regarding the authors, institutions, countries and journal titles were normalized. There were several different entries for a single author or institution to be checked and unified, both on macro (i.e. universities and research centers) and micro (i.e. individual departments and research units) levels. Articles originating from Serbia and Montenegro, since they were published after 1996, were reclassified as being from Serbia. Regarding the journals, only one had different entries that had to be unified due to the change of title.

\section{RESULTS}

Complete details of the 102 top cited articles affiliated to Serbian dental institutions or departments were listed in the Appendix (available online) in descending order based on the number of citations obtained. The equally cited articles were sorted chronologically in accordance with the publication date (e.g. papers with the Article ID 11 and 12 in the Appendix).

The set of studied articles received in total 4,598 citations during the period 1996-2018. The average number of citations per article found in this study was 45.08 . The most common document type were journal papers, including original research $(\mathrm{n}=92)$ and review articles $(n=8)$, as well as two proceedings papers, published between 1997 and 2016 (Table 1).

Table 1. Number and types of top cited articles

Tabela 1. Broj i tip najcitiranijih radova

\begin{tabular}{|c|c|c|c|c|}
\hline $\begin{array}{l}\text { Year } \\
\text { Godina }\end{array}$ & $\begin{array}{l}\text { Article } \\
\text { Članak }\end{array}$ & $\begin{array}{l}\text { Proceedings Paper } \\
\text { Radovi sa kongresa }\end{array}$ & $\begin{array}{c}\text { Review } \\
\text { Revijski radovi }\end{array}$ & $\begin{array}{c}\text { Total } \\
\text { Ukupno }\end{array}$ \\
\hline 1997 & 1 & & & 1 \\
\hline 1999 & 1 & & & 1 \\
\hline 2000 & 1 & & & 1 \\
\hline 2001 & 2 & & & 2 \\
\hline 2002 & 1 & & & 1 \\
\hline 2003 & 1 & & & 1 \\
\hline 2005 & 6 & & & 6 \\
\hline 2006 & 4 & & & 4 \\
\hline 2007 & 17 & & 1 & 18 \\
\hline 2008 & 6 & 1 & 2 & 9 \\
\hline 2009 & 10 & & 1 & 11 \\
\hline 2010 & 10 & & 1 & 11 \\
\hline 2011 & 10 & & & 10 \\
\hline 2012 & 10 & & 1 & 11 \\
\hline 2013 & 6 & & 1 & 7 \\
\hline 2014 & 2 & 1 & & 3 \\
\hline 2015 & 3 & & 1 & 4 \\
\hline 2016 & 1 & & & 1 \\
\hline $\begin{array}{l}\text { Total } \\
\text { Ukupno }\end{array}$ & 92 & 2 & 8 & 102 \\
\hline
\end{tabular}

The distribution of these top cited documents with respect to the publication year and total citation count is shown in Graph 1. The citation count of selected articles ranged between 23 (ArticleID 99-102) and 226 (top cited article). The top five articles were cited more than 100 


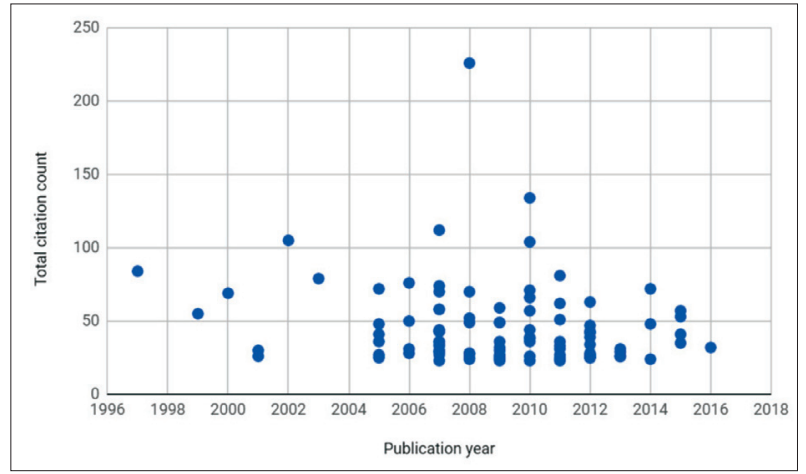

Graph 1. Distribution of the 102 top cited documents per year of publication and total citation count.

Grafikon 1. Raspodela najbolje citirana 102 članka po godini publikovanja i ukupnom broju citata

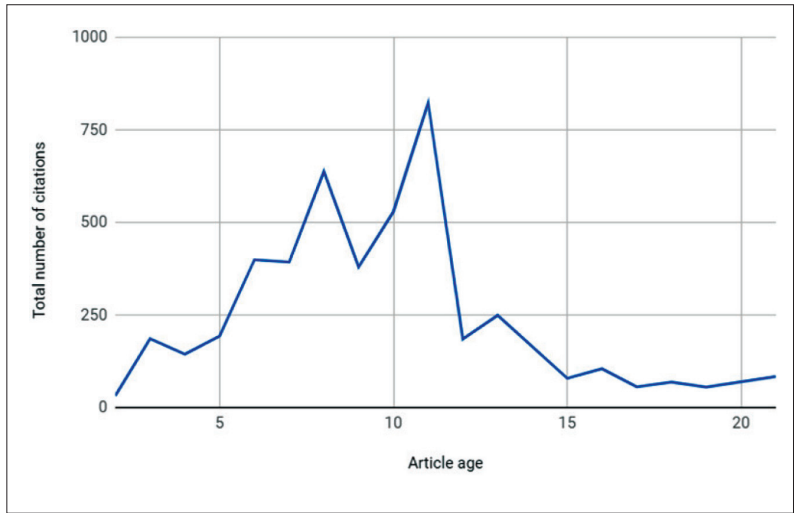

Graph 2. The total number of citations with respect to age of articles Grafikon 2. Ukupan broj citata prema godini starosti članaka

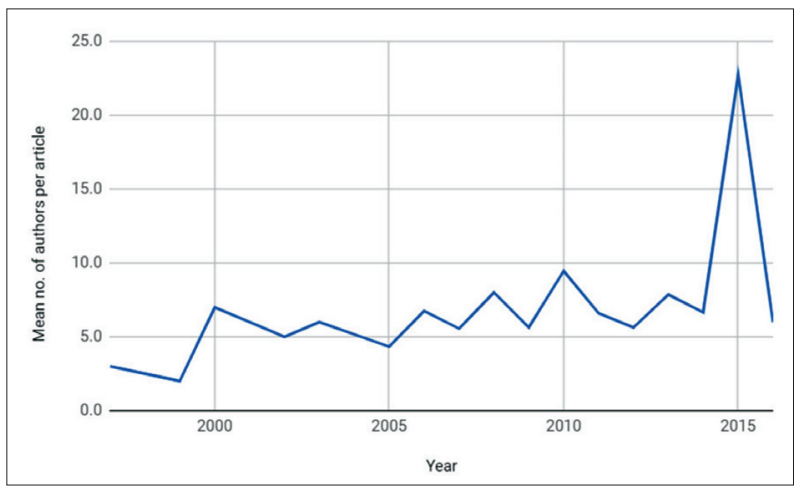

Graph 3. Mean number of authors per paper with respect to year Grafikon 3. Srednja vrednost ukupnog broj autora po članku prema godini publikovanja

times, while the most referenced article $(c=226)$ was a review paper published in 2008. Out of total number of selected papers, nearly $52 \%$ appeared in period 2006-2010, while $35.3 \%$ and $10.8 \%$ were published in 2011-2016 and 2000-2005, respectively. Only a small number of papers $(n=2)$ date from 1996-1999. The year 2007 was the year with the greatest number of published top cited articles $(n=18)$, followed by 2009,2010 and $2012(n=11)$. In addition, the five top cited articles were published in 2002, 2007, 2008 and 2010.

The top 102 articles' total number of citations with respect to their age is shown in Graph 2. The greatest total number of citations $(c=822)$ had 18 articles published
11 years ago. On the other hand, the articles 8 years old received the total of 638 citations and it was the greatest number of citations per year $(\mu=79.8)$. The most cited original research article was: Jensen $S B$, Pedersen $A M L$, Vissink A et al. A systematic review of salivary gland hypofunction and xerostomia induced by cancer therapies: management strategies and economic impact. Supportive Care in Cancer. 2010;18(8):1061-79 (Article ID 1); while the most cited review paper was: Radovic I, Monticelli F, Goracci C, Vulicevic ZR, Ferrari M. Self-adhesive resin cements: A literature review. Journal of Adhesive Dentistry. 2008;10(4):251-8 (Article ID 2).

\section{Journals}

One hundred and two (102) most influential articles affiliated to Serbian dental institutions or departments were published in 60 journals. Journals with the highest contribution of articles were Journal of Periodontology, Dental Materials and Clinical Oral Implants Research $(\mathrm{n}=15)$ followed by the Journal of Clinical Periodontology, Journal of Endodontics and Oral Surgery, Oral Medicine, Oral Pathology, Oral Radiology $(\mathrm{n}=12)$. Out of the total number of journals, 39 (65\%) contained only one article, while the remaining $25 \%$ of the journal titles had two or three articles. Table 2 displays the most influential journal titles with respect to received number of citations, as well as their Quartile rankings based on Impact Factor data from the 2017 edition of Journal Citation Reports. Even though the most of the top cited articles were published in high ranked journals, article that stands out in terms of received citation number was published in American Journal of Dentistry, which is ranked at the lowest position of the subject category IF distribution. Source publications of the top cited articles are distributed in 40 the Web of Science subject categories. Slightly more than a half of journals belong to Dentistry, Oral Surgery \& Medicine, while the other subject areas have assigned 12\% (e.g. Materials Science, Biomaterials; Engineering, Biomedical; Surgery) or less journal titles.

\section{Authors, Institutions and Countries}

The frequency of occurrence of all authors was recorded in detail. There were 449 authors, responsible for 726 authorships, affiliated to 149 institutions from 41 countries. The number of authors of the top cited articles ranged from 2-32, while the mean number of authors per paper was 7 . Since the three large studies (Article ID 23, 43, 54), authored with 22.8 authors per paper, were conducted in 2015 , the average number of authors per article increased from 2.5 in 1990s to 7.5 in 2000s (Graph 3). Beside these articles published in 2015, there were three other studies with more than 20 co-authors (Article ID 2, 5, 32). A great deal of articles (40.2\%) was co-authored by more than 6 researchers, whereas 22 articles had 6 authors. Out of the 102 top cited papers, 5, 8, 10 and 16 papers were written by two, three, four and five authors, respectively.

There were 72 researchers who contributed to the top cited articles as first authors. Table 3 outlines the most 
Table 2. Characteristics of the top 15 journals

Tabela 2. Karakteristike najboljih 15 časopisa

\begin{tabular}{|c|c|c|c|c|c|}
\hline $\begin{array}{l}\text { Journal } \\
\text { Časopis }\end{array}$ & $\begin{array}{c}\text { Total citations } \\
\begin{array}{c}\text { Ukupan broj } \\
\text { citata }\end{array} \\
\end{array}$ & $\begin{array}{c}\text { Total articles } \\
\text { Ukupan broj } \\
\text { članaka }\end{array}$ & $\begin{array}{c}\text { Citations per article } \\
\text { Broj citata po } \\
\text { članku }\end{array}$ & $\begin{array}{l}\text { Quartile in } \\
\text { Category } \\
\text { Kvartil }\end{array}$ & $\begin{array}{l}\text { WoS category } \\
\text { WoS kategorija }\end{array}$ \\
\hline JOURNAL OF PERIODONTOLOGY & 261 & 5 & 52.2 & Q1 & Dentistry, Oral Surgery \& Medicine \\
\hline JOURNAL OF ADHESIVE DENTISTRY & 260 & 2 & 130.0 & Q2 & Dentistry, Oral Surgery \& Medicine \\
\hline \multirow{2}{*}{ SUPPORTIVE CARE IN CANCER } & \multirow{2}{*}{238} & \multirow{2}{*}{2} & \multirow{2}{*}{119.0} & \multirow{2}{*}{ Q1 } & Health Care Sciences \& Services \\
\hline & & & & & Oncology \\
\hline JOURNAL OF CLINICAL PERIODONTOLOGY & 203 & 4 & 50.8 & Q1 & Dentistry, Oral Surgery \& Medicine \\
\hline JOURNAL OF ENDODONTICS & 198 & 4 & 49.5 & Q1 & Dentistry, Oral Surgery \& Medicine \\
\hline \multirow{2}{*}{ DENTAL MATERIALS } & \multirow{2}{*}{173} & \multirow{2}{*}{5} & \multirow{2}{*}{34.6} & \multirow{2}{*}{ Q1 } & Dentistry, Oral Surgery \& Medicine \\
\hline & & & & & Materials Science, Biomaterials \\
\hline \multirow{2}{*}{$\begin{array}{l}\text { INTERNATIONAL JOURNAL OF ORAL AND } \\
\text { MAXILLOFACIAL SURGERY }\end{array}$} & \multirow{2}{*}{172} & \multirow{2}{*}{3} & \multirow{2}{*}{57.3} & \multirow{2}{*}{ Q2 } & Dentistry, Oral Surgery \& Medicine \\
\hline & & & & & Surgery \\
\hline \multirow{2}{*}{ ORAL ONCOLOGY } & \multirow{2}{*}{162} & \multirow{2}{*}{3} & \multirow{2}{*}{54} & \multirow{2}{*}{ Q1 } & Dentistry, Oral Surgery \& Medicine \\
\hline & & & & & Oncology \\
\hline \multirow{2}{*}{ CLINICAL ORAL IMPLANTS RESEARCH } & \multirow{2}{*}{150} & \multirow{2}{*}{5} & \multirow{2}{*}{30} & \multirow{2}{*}{ Q1 } & Dentistry, Oral Surgery \& Medicine \\
\hline & & & & & Engineering, Biomedical \\
\hline EUROPEAN JOURNAL OF ORAL SCIENCES & 139 & 3 & 46.3 & Q2 & Dentistry, Oral Surgery \& Medicine \\
\hline CLINICAL ORAL INVESTIGATIONS & 123 & 2 & 61.5 & Q1 & Dentistry, Oral Surgery \& Medicine \\
\hline JOURNAL OF DENTISTRY & 119 & 3 & 39.7 & Q1 & Dentistry, Oral Surgery \& Medicine \\
\hline AMERICAN JOURNAL OF DENTISTRY & 112 & 1 & 112.0 & Q4 & Dentistry, Oral Surgery \& Medicine \\
\hline $\begin{array}{l}\text { ORAL SURGERY ORAL MEDICINE ORAL } \\
\text { PATHOLOGY ORAL RADIOLOGY }\end{array}$ & 106 & 4 & 26.5 & Q2 & Dentistry, Oral Surgery \& Medicine \\
\hline \multirow{2}{*}{$\begin{array}{l}\text { JOURNAL OF MATERIALS } \\
\text { SCIENCE-MATERIALS IN MEDICINE }\end{array}$} & \multirow{2}{*}{106} & \multirow{2}{*}{3} & \multirow{2}{*}{35.3} & \multirow{2}{*}{ Q2 } & Engineering, Biomedical \\
\hline & & & & & Materials Science, Biomaterials \\
\hline
\end{tabular}

Table 3. Top 15 contributing authors with respect to the number of published papers

Tabela 3. Najboljih 15 autora prema broju publikovanih članaka

\begin{tabular}{|l|l|c|c|c|}
\hline $\begin{array}{l}\text { Authors } \\
\text { Autori }\end{array}$ & $\begin{array}{l}\text { Affiliations } \\
\text { Afilijacija }\end{array}$ & $\begin{array}{c}\text { Number of articles } \\
\text { Broj članaka }\end{array}$ & $\begin{array}{c}\text { Total number of citations } \\
\text { Ukupan broj citata }\end{array}$ & $\begin{array}{c}\text { First author } \\
\text { Prvi autor }\end{array}$ \\
\hline Ferrari, Marco & Univ Siena, Policlin Le Scotte, Italy & 13 & 830 & 1 \\
\hline Radović, Ivana & Univ Belgrade, Sch Dent, Serbia & 12 & 782 & 4 \\
\hline Leković, Vojislav & Univ Belgrade, Sch Dent, Serbia & 12 & 658 & 4 \\
\hline Kenney, E. Barrie & Univ Calif Los Angeles, Sch Dent, USA & 9 & 530 & 0 \\
\hline Goracci, Cecilia & Univ Siena, Policlin Le Scotte, Italy & 8 & 581 & 1 \\
\hline Camargo, Paulo M. & Univ Calif Los Angeles, Sch Dent, USA & 8 & 456 & 4 \\
\hline Weinlaender, Michael & Univ Calif Los Angeles, Sch Dent, USA & 8 & 436 & 1 \\
\hline Milašin, Jelena & Univ Belgrade, Sch Dent, Serbia & 7 & 289 & 0 \\
\hline Čolić, Miodrag & Mil Med Acad, Inst Med Res, Serbia & 7 & 279 & 4 \\
\hline Ignjatović, Nenad & Serbian Acad Arts \& Sci, Inst Tech Sci, Serbia & 7 & 194 & 0 \\
\hline Uskoković, Dragan & Serbian Acad Arts \& Sci, Inst Tech Sci, Serbia & 7 & 194 & 0 \\
\hline Vasilić, N & Univ Calif Los Angeles, Sch Dent, USA & 6 & 381 & 1 \\
\hline Kozomara, Ružica J. & Mil Med Acad, Clin Maxillofacial \& Oral Surg, Serbia & 6 & 265 & \\
\hline Marković, Aleksa & Univ Belgrade, Sch Dent, Serbia & 6 & 198 & 1 \\
\hline Ajduković, Zorica & Univ Nis, Fac Med Clin Stomatol, Serbia & 6 & 166 & 4 \\
\hline
\end{tabular}

productive authors regarding the total number of published papers. As indicated, Ferrari tops the list with a total of 13 publications, followed by Radović, Leković, Kenney, Goracci, Camargo and Weinlaender, each of which has more than 7 publications. It should be noted that a number of papers were co-authored by these authors. For instance, Ferrari, Radović and Goracci have co-authored 12 papers in the past 11 years. Furthermore, another group of authors i.e. Leković, Kenney, Camargo and Weinlaender have co-authored 7 papers.

Among the overall number of authors, 238 were from Serbia, while 211 were affiliated with foreign institutions.
The top 20 Serbian authors who contributed the most as first authors are listed in Table 4. Ignjatović was the author with the highest number of first author papers, followed by Radović, Leković, Čolić and Marković.

According to the information on author addresses contained in the research papers, 69 articles were contributed by international collaboration, while the remaining 33 were independent Serbian articles. There were 108 authors from Serbian dental institutions or departments, whereas 130 were from other Serbian institutions. Countries contributing to the top cited articles affiliated to Serbian dental institutions or departments are depicted 
Table 4. Top 20 contributing authors affiliated to Serbian institutions, with respect to the number of papers where they are first author, total number of published papers and cumulative number of citations for all their articles

Tabela 4. Najboljih 20 autora iz institucija iz Srbije prema broju članaka gde su prvi autori, ukupan broj objavljenih članaka i ukupan broj citata za sve njihove članke

\begin{tabular}{|c|c|c|c|c|}
\hline $\begin{array}{l}\text { Authors } \\
\text { Autori }\end{array}$ & $\begin{array}{l}\text { Affiliations } \\
\text { Afilijacija }\end{array}$ & $\begin{array}{l}\text { First Author } \\
\text { Prvi autor }\end{array}$ & $\begin{array}{c}\text { Total number of citations } \\
\text { Ukupan broj citata }\end{array}$ & $\begin{array}{c}\text { Number of articles } \\
\text { Broj članaka }\end{array}$ \\
\hline Ignjatović, Nenad & Serbian Acad Arts \& Sci, Inst Tech Sci & 6 & 194 & 7 \\
\hline Radović, Ivana & Univ Belgrade, Sch Dent & 4 & 782 & 12 \\
\hline Leković, Vojislav & Univ Belgrade, Sch Dent & 4 & 658 & 12 \\
\hline Čolić, Miodrag & Mil Med Acad, Inst Med Res & 4 & 279 & 7 \\
\hline Marković, Aleksa & Univ Belgrade, Sch Dent & 4 & 198 & 6 \\
\hline Šupić, Gordana & Mil Med Acad, Inst Med Res & 3 & 239 & 5 \\
\hline Brković, Božidar M. B. & Univ Belgrade, Sch Dent & 2 & 103 & 3 \\
\hline Djurić, Marija R. & Univ Belgrade, Fac Med & 2 & 93 & 3 \\
\hline Mandinić, Zoran & Univ Belgrade, Sch Dent & 2 & 83 & 2 \\
\hline Pejčić, Ana & Univ Nis, Fac Med Clin Stomatol & 2 & 65 & 2 \\
\hline Kozomara, Ružica J. & Mil Med Acad, Clin Maxillofacial \& Oral Surg & 1 & 265 & 6 \\
\hline Ajduković, Zorica & Univ Nis, Fac Med Clin Stomatol & 1 & 166 & 6 \\
\hline Gazivoda, Dragan & Mil Med Acad, Clin Maxillofacial \& Oral Surg & 1 & 147 & 4 \\
\hline Miletić, Vesna & Univ Belgrade, Sch Dent & 1 & 109 & 3 \\
\hline Zeljić, Katarina & Mil Med Acad, Inst Med Res & 1 & 109 & 3 \\
\hline Dimitrijević, Milovan V. & $\begin{array}{l}\text { Clin Ctr Serbia, Clin Otorhinolaryngol } \\
\text { \& Maxillofacial Surg }\end{array}$ & 1 & 98 & 2 \\
\hline Jevremović, Danimir & $\begin{array}{l}\text { Univ Business Acad Novi Sad, } \\
\text { Fac Stomatol Pancevo }\end{array}$ & 1 & 79 & 2 \\
\hline Obradović, Radmila R. & Univ Nis, Fac Med Clin Stomatol & 1 & 68 & 2 \\
\hline Daković, Dragana & Mil Med Acad & 1 & 60 & 2 \\
\hline Jurišić, Milan & Univ Belgrade, Sch Dent & 1 & 52 & 2 \\
\hline
\end{tabular}

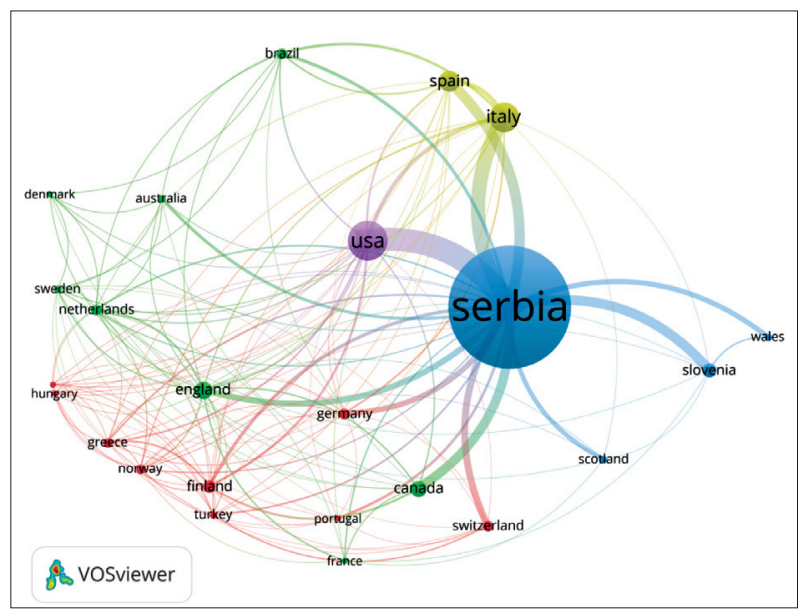

Figure 1. Contributing countries

Slika 1. Države iz kojih dolaze članci

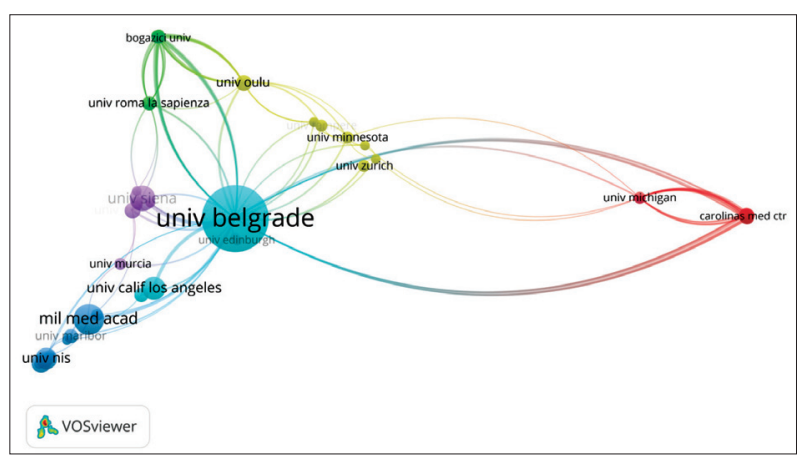

Figure 2. Most productive universities

Slika 2. Najproduktivniji univerziteti
Table 5. Most productive top cited institutions

Tabela 5. Najproduktivnije institucije, sa najvećim brojem citata

\begin{tabular}{|l|c|}
\hline $\begin{array}{l}\text { Institution } \\
\text { Institucija }\end{array}$ & $\begin{array}{c}\text { Number of articles } \\
\text { Broj članaka }\end{array}$ \\
\hline University of Belgrade, Serbia & 80 \\
\hline Military Medical Academy, Serbia & 18 \\
\hline University of Siena, Italy & 12 \\
\hline University of Niš, Serbia & 11 \\
\hline University of California Los Angeles, USA & 10 \\
\hline Serbian Academy of Arts \& Sciences, Serbia & 7 \\
\hline University Business Academy Novi Sad, Serbia & 6 \\
\hline University of Granada, Spain & 5 \\
\hline University of Novi Sad, Serbia & 5 \\
\hline University of Oulu, Finland & 5 \\
\hline
\end{tabular}

in Figure 1, with respect to their number of co-authored articles. Among 41 countries only 13 had first author articles (Austria, Canada, Denmark, England, Germany, Italy, Netherlands, Scotland, Serbia, Spain, Sweden, Switzerland, and USA). Beside Serbia, the top countries were represented with more than 6 national institutions. The greatest number of institutions $(\mathrm{n}=23)$ originated from the USA, followed by England ( $n=10)$, Italy $(n=9)$, Germany $(n=8)$, and Canada and Spain $(n=6)$. The top two most productive institutions were the University of Belgrade and Military Medical Academy from Serbia (Table 5). They were followed by University of Siena, University of Niš, University of California Los Angeles etc. Out of the total number of institutions, there were 102 universities and the most productive are illustrated in Figure 2. 


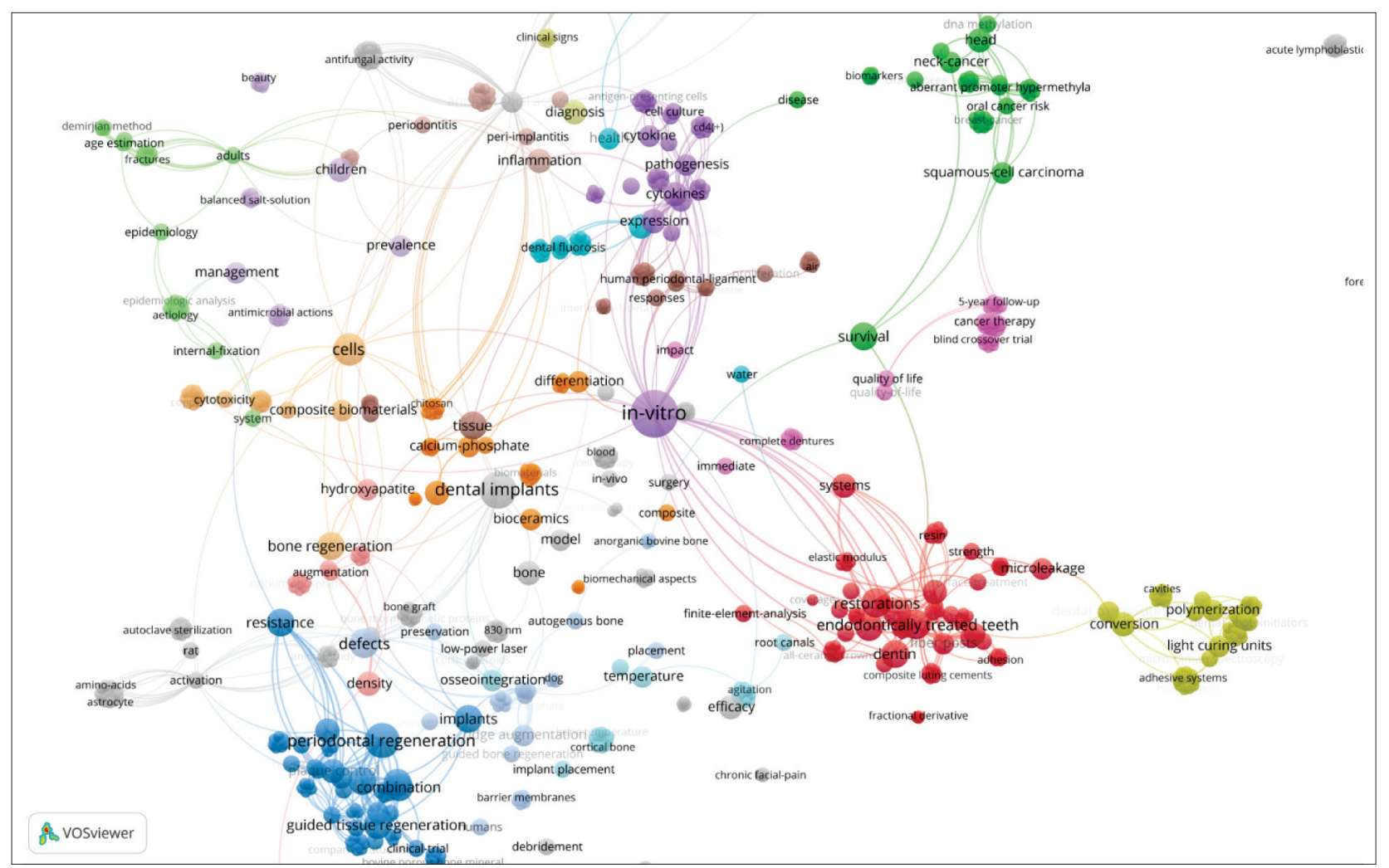

Figure 3. Clusters based on co-occurrence of keywords

Slika 3. Klasteri zasnovani na zajedničkom pojavljivanju ključnih reči

\section{KEYWORDS}

Of the 102 top cited articles, a total of 176 keywords were identified. The most frequently used author keywords $(\mathrm{n}=77)$ and KeyWords Plus $(\mathrm{n}=99)$, with respect to the number of times they appear in the analyzed articles are presented in Figure 3. The most productive keywords with interconnected links are shown, while the different clusters are illustrated through coloring.

\section{DISCUSSION}

This bibliometric study aimed to identify the top cited articles affiliated to Serbian dental institutions or departments and their main characteristics, in order to reveal the achieved Serbian scientific progress in the field of dentistry, as well as trends in Serbian dental research. Even though the studying of the citation count is widespread [2, 3, 6, 8-11, 15, 20-27], this value could not be treated as an absolute scientific quality indicator, but it can provide an objective and quantitative measure that an article has made on the scientific community in its respective field [28,29]. The top 102 articles affiliated to Serbian dental institutions or departments were cited between 23 and 261 times. The top five articles were cited at least 100 times, and according to the previous studies in the field, they could be characterized as citation classics [16]. However, it should be noted that the obtained number of citations is far below the citation rates in larger medical fields [30,31].
In our study, almost all investigated articles were published in journals that occupy top or middle-high positions in their respective subject category. Citations are largely driven by publication records, but they are also substantially increased by larger research teams and coauthor networks [32]. Collaboration is a significant factor in scholarly productivity, but varies by discipline [1]. Collaborative research is typical of most scientific disciplines, as well of medicine. The mean number of authors per paper found in this study was 7, which is slightly higher than the mean number of authors per article revealed in other studies in the field of dentistry [11]. Since the six large studies, authored with more than 22 authors per paper, were conducted, the mean number of authors per article increased from 2.5 in 1990 s to 7.5 in 2000s. The identified co-author networks were the crucial factors in determining the distribution of institutions and countries. The majority of articles originated from the collaboration with the researchers from the USA, as well as European institutions, i.e. Italy, Spain and Finland.

The author keywords provide reasonably detailed picture of the article's themes, while KeyWords Plus, generated independently of the author keywords, describe the article's content with greater depth and variety [33]. In order to overcome the limitations of investigating relatively small sample of author keywords, for the analysis and representation of the article's themes KeyWords Plus were also used.

From a methodological point of view, there are some limitations associated with the study. For the identification of top cited articles affiliated to Serbian dental insti- 
tutions and departments only the Web of Science database was used, while other databases were not covered. Therefore, some important articles published in journals that are not included in the Web of Science might be missed. In addition, the self-citations were not excluded from the total number of citations encountered by an article, which may inflate the citation rate. Besides, for the analysis of authorships, the whole counting method was used instead of fractional. Finally, a content analysis of the influential articles was not performed, including the most frequent scope and design of study, as well as level of evidence.

Despite these obvious limitations, the data presented in this study still provide significant insight into the achievements and evolving trends in Serbian dental research over the past decades. To the best of authors' knowledge, this is the first report of the top cited articles affiliated to Serbian dental institutions or departments.

\section{CONCLUSION}

The present work explores the characteristics of the 102 top cited articles affiliated to Serbian dental institutions or departments during 1996-2018 within the Web of Science database. This bibliometric analysis reveals the escalating course in the mean citation number of these top articles, highlighting the trends in the Serbian dental research literature. Since the citation counts are continuously changing, results presented in this study provide a snapshot of the most influential articles affiliated to Serbian dental institutions and departments of the current time.

The set of top cited papers were published in 60 journals from 1997 to 2016, with the mean number of 45.08 citations per article. These papers were co-authored by 449 authors, responsible for 726 authorships, affiliated to 149 institutions from 41 countries. Among the overall number of authors, 238 were from Serbia, while 211 were affiliated with foreign institutions. The top Serbian authors who contributed the most with respect to the number of published articles were Radović Ivana and Leković Vojislav, followed by Milašin Jelena, Čolić Miodrag and Ignjatović Nenad. The most productive institutions were the University of Belgrade and Military Medical Academy from Serbia, whilest the foreign contributing institutions were primariliy from the USA, England, Italy, Germany, Canada and Spain. The revealed multi-institutional and international collaborations encourage higher quality research. Beside Dentistry, Oral Surgery and Medicine, the top cited articles were published in journals that belong to various Web of Science subject categories, revealing in that way the multidisciplinary nature of the investigated top cited articles research.

In order to provide more comprehensive insight into this literature, it would be very useful to conduct finer content analysis and classification of the investigated top cited articles affiliated to Serbian dental institutions and departments. Future studies covering these issues are desirable in order to introduce to new researchers approaches and methods applied in the top cited papers and help them to spot current impactful and emergent topics.

\section{REFERENCES}

1. Borgman CL, Furner J. Scholarly communication and bibliometrics. Annual Review of Information Science and Technology. 2002; 36(1):2-72. [DOI: 10.1002/aris.1440360102]

2. Prevezanos P, Tsolakis Al, Christou P. Highly cited orthodontic articles from 2000 to 2015. American Journal of Orthodontics and Dentofacial Orthopedics. 2018; 153(1):61-9.

[DOI: 10.1016/j.ajodo.2017.06.015] [PMID: 29287655]

3. Fardi A, Kodonas K, Lillis T, Veis A. Top-Cited Articles in Implant Dentistry. International Journal of Oral \& Maxillofacial Implants. 2017; 32(3):555-64. [DOI: 10.11607/jomi.5331] [PMID: 28494039]

4. Azer SA. Top-Cited Articles in Problem-Based Learning: A Bibliometric Analysis and Quality of Evidence Assessment. Journal of Dental Education. 2017; 81(4):458-78. [DOI: 10.21815/JDE.016.011] [PMID: 28365611]

5. Smith DR. Highly-cited articles in the Australian Dental Journal. Australian Dental Journal. 2008; 53(3):265-6.

[DOI: 10.1111/j.1834-7819.2008.00059.x] [PMID: 18782372]

6. Pena-Cristobal M, Diniz-Freitas M, Monteiro L, Dios PD, Warnakulasuriya S. The 100 most cited articles on oral cancer. Journal of Oral Pathology \& Medicine. 2018; 47(4):333-44.

[DOI: 10.1111/jop.12686] [PMID: 29380894]

7. Foy JP, Bertolus C, Goudot P, Deneuve S, Blanc E, Lasset C, et al. Bibliometric analysis of a century of research on oral erythroplakia and leukoplakia. Journal of Oral Pathology \& Medicine. 2018; 47(4):388-95. [DOI: 10.1111/jop.12683] [PMID: 29344996]

8. Gondivkar SM, Sarode SC, Gadbail AR, Gondivkar RS, Chole R, Sarode GS. Bibliometric analysis of 100 most cited articles on oral submucous fibrosis. Journal of Oral Pathology \& Medicine. 2018; 47(8):781-7. [DOI: 10.1111/jop.12742] [PMID: 29905986]

9. Aslam-Pervez N, Lubek JE. Most cited publications in oral and maxillofacial surgery: a bibliometric analysis. Oral and Maxillofacial Surgery-Heidelberg. 2018; 22(1):25-37.

[DOI: 10.1007/s10006-017-0660-z] [PMID: 29101582]

10. Mahon NA, Joyce CW. A bibliometric analysis of the 50 most cited papers in cleft lip and palate. Journal of Plastic Surgery and Hand Surgery. 2015; 49(1):52-8. [DOI: 10.3109/2000656X.2014.951053] [PMID: 25196126]

11. Tarazona B, Vidal-Infer A, Alonso-Arroyo A. Bibliometric analysis of the scientific production in implantology (2009-2013). Clinical Oral Implants Research. 2017; 28(7):864-70. [DOI: 10.1111/clr.12891] [PMID: 27255795]

12. Alarcon MA, Esparza D, Montoya C, Monje A, Faggion CM. The 300 Most-Cited Articles in Implant Dentistry. International Journal of Oral \& Maxillofacial Implants. 2017; 32(1):e1-8. [DOI: 10.11607/jomi.5104] [PMID: 27706262]

13. Fardi A, Kodonas K, Gogos C, Economides N. Top-cited Articles in Endodontic Journals. Journal of Endodontics. 2011; 37(9):1183-90. [DOI: 10.1016/j.joen.2011.05.037] [PMID: 21846531]

14. Hui JF, Han ZK, Geng GN, Yan WJ, Shao P. The 100 top-cited articles in orthodontics from 1975 to 2011. Angle Orthodontist. 2013; 83(3):491-9. [DOI: 10.2319/040512-284.1] [PMID: 23050741]

15. Tarazona B, Lucas-Dominguez R, Paredes-Gallardo V, Alonso-Arroyo A, Vidal-Infer A. The 100 most-cited articles in orthodontics: A bibliometric study. Angle Orthodontist. 2018; 88(6):785-96. [DOI: 10.2319/012418-65.1] [PMID: 30102086]

16. Nieri M, Saletta D, Guidi L, Buti J, Franceschi D, Mauro S, et al. Citation classics in periodontology: a controlled study. Journal of Clinical Periodontology. 2007; 34(4):349-58.

[DOI: 10.1111/j.1600-051X.2007.01060.x] [PMID: 17378889]

17. Faggion CM, Malaga L, Monje A, Trescher AL, Listl S, Alarcon MA. The 300 most cited articles published in periodontology. Clinical Oral Investigations. 2017; 21(6):2021-8.

[DOI: 10.1007/s00784-016-1990-1] [PMID: 27844151]

18. Persson O, Danell R, Schneider JW. How to use Bibexcel for various types of bibliometric analysis. In: Åström F, Danell R, Larsen B, Schneider J, editors. Celebrating scholarly communication studies: A Festschrift for Olle Persson at his 60th Birthday. 5: International Society for Scientometrics and Informetrics Leuven, Belgium; 2009. p. 9-24. 
19. van Eck NJ, Waltman L. Citation-based clustering of publications using CitNetExplorer and VOSviewer. Scientometrics. 2017; 111(2):1053-70.

20. Chiang HS, Huang RY, Weng PW, Mau LP, Su CC, Tsai YWC, et al. Increasing prominence of implantology research: a chronological trend analysis of 100 top-cited articles in periodontal journals. European Journal of Oral Implantology. 2018; 11(1):97-110. [PMID: 29557404]

21. Muniz F, Celeste RK, Oballe HJR, Rosing CK. Citation analysis and trends in review articles in dentistry. Journal of Evidence-Based Dental Practice. 2018; 18(2):110-8.

[DOI: 10.1016/j.jebdp.2017.08.003] [PMID: 29747791]

22. Susarla SM, Tveit M, Dodson TB, Kaban LB, Hopper RA, Egbert MA. What are the defining characteristics of the most cited publications in orthognathic surgery? International Journal of Oral and Maxillofacial Surgery. 2018; 47(11):1411-9.

[DOl: 10.1016/j.ijom.2018.04.016] [PMID: 29793896]

23. Corbella S, Francetti L, Taschieri S, Weinstein R, Del Fabbro M. Analysis of the 100 most-cited articles in periodontology. Journal of Investigative and Clinical Dentistry. 2017; 8(3):e12222. [DOI: 10.1111/jicd.12222] [PMID: 27339659]

24. Tahim A, Patel K, Bridle C, Holmes S. The 100 Most Cited Articles in Facial Trauma: A Bibliometric Analysis. Journal of Oral and Maxillofacial Surgery. 2016; 74(11):2240.e1-14.

[DOI: 10.1016/j.joms.2016.06.175] [PMID: 27431204]

25. Christou P, Antonarakis GS. The 100 Most-Cited Human Cleft Lip and Palate-Related Articles Published in Dentistry, Oral Surgery, and Medicine Journals. Cleft Palate-Craniofacial Journal. 2015; 52(4):437-46. [DOI: 10.1597/14-085] [PMID: 25275538]

26. Jafarzadeh $H$, Shirazi AS, Andersson L. The most-cited articles in dental, oral, and maxillofacial traumatology during 64 years. Den- tal Traumatology. 2015; 31(5):350-60. [DOI: 10.1111/edt.12195] [PMID: 26086206]

27. Tahiri Y, Fleming TM, Greathouse T, Tholpady SS. Analysis of the 50 most cited papers in craniofacial surgery. Journal of CranioMaxillofacial Surgery. 2015; 43(10):2152-7.

[DOI: 10.1016/j.jcms.2015.09.011] [PMID: 26541748]

28. Garfield E. Citation indexing - its theory and application in science, technology, and humanities. New York: Wiley; 1979.

29. Ioannidis JPA. Concentration of the Most-Cited Papers in the Scientific Literature: Analysis of Journal Ecosystems. Plos One. 2006; 1(1):e5. [DOI: 10.1371/journal.pone.0000005] [PMID: 17183679]

30. Hachem LD, Mansouri A, Juraschka K, Taslimi S, Pirouzmand F, Zadeh G. Citation classics in neuro-oncology: assessment of historical trends and scientific progress. Neuro-Oncology. 2017; 19(9):1158-72. [DOI: 10.1093/neuonc/nox053] [PMID: 28531344]

31. Usman MS, Siddiqi TJ, Khan MS, Fatima K, Butler J, Manning WJ, et al. A Scientific Analysis of the 100 Citation Classics of Valvular Heart Disease. American Journal of Cardiology. 2017; 120(8):1440-9. [DOI: 10.1016/j.amjcard.2017.07.035] [PMID: 28838604]

32. Bosquet C, Combes PP. Are academics who publish more also more cited? Individual determinants of publication and citation records. Scientometrics. 2013; 97(3):831-57. [DOI: 10.1007/s11192013-0996-6]

33. Garfield E, Sher IH. KeyWords Plus ${ }^{\mathrm{m}}$ - algorithmic derivative indexing. Journal of the American Society for Information Science. 1993; 44(5):298-9.

[DOI: 10.1002/(SICI)1097-4571(199306)44:5<298::AID-ASI5>3.0.CO;2-A]

Received: 17.09.2018 • Accepted: Prihvaćen 03.12.2018 


\title{
Najcitiraniji radovi istraživača srpskih stomatoloških institucija (1996-2018)
}

\author{
Jelena Jaćimović \\ Univerzitet u Beogradu, Stomatološki fakultet, Centralna biblioteka, Beograd, Srbija
}

\begin{abstract}
KRATAK SADRŽAJ
Uvod Citatna analiza, kao jedan od najpoznatijih bibliometrijskih pristupa, u velikoj meri se koristi prilikom procene naučnih rezultata, postignutog istraživačkog učinka i uticaja. Cilj ovoga rada bio je identifikacija najcitiranijih članaka koje su objavili istraživači povezani sa srpskim stomatološkim institutcijama, kao i analiza njihovih odlika, radi opisa ostvarene saradnje, kako na individualnom $\mathrm{i}$ institucionalnom, tako i na nacionalnom i internacionalnom nivou.

Materijal i metode Članci sa najvećim brojem citata dobijenih u okviru baze Web of Science od datuma publikovanja do 2018. godine bili su predmet procene. Aspekti koji su analizirani obuhvatali su podatke o broju objavljenih članaka na godišnjem nivou, broju dobijenih citata u toku godine, časopisima, predmetnim kategorijama, zemljama, institucijama, autorima, ali i centralnim temama i trendovima u istraživanjima, posmatranim na osnovu ključnih reči koje je autor dodelio članku, ali i dodatnih ključnih reči, generisanih u okviru korišćene baze Web of Science (KeyWords Plus).

Rezultati Posmatrana grupa najcitiranijih radova objavljena je u okviru 60 različitih časopisa, u periodu od 1997. do 2016. godine, uz 45,08 prosečan broj citata po radu. U izradi ovih članaka učestvovalo je ukupno 449 autora, odgovornih za 726 autorstava i povezanih sa 149 institucija iz 41 zemlje. Od ukupnog broja autora, 238 je iz Srbije, dok je 211 autora vezano za strane institucije. Najproduktivnije ustanove iz Srbije bile su Univerzitet u Beogradu i Vojnomedicinska akademija, dok su strane institucije koje su učestvovale u izradi radova prevashodno dolazile iz SAD, Engleske i Italije.

Zaključak Ova studija pruža koristan uvid u to koja su istraživanja srpskih stomatoloških ustanova izvršila najveći uticaj, otkrivajući i najproduktivnije aktere i multidisciplinarnu prirodu naučnog doprinosa.

Ključne reči: bibliometrija; citatna analiza; Srbija; stomatologija, oralna hirurgija i medicina
\end{abstract}

\section{UVOD}

Bibliometrija je primenjivana u različitim oblicima za izučavanje strukture i procesa naučnih komunikacija [1]. Ovaj moćan skup metoda i mera korišćen je kao praktičan alat koji nam omogućava upoznavanje sa ponašanjem svojstvenim naučnim komunikacijama kroz ukupnu produkciju naučne literature na makronivoima, ali i mikronivoima analize. Bibliometrijski pokazatelji nude mogućnost kvantitativnog sagledavanja naučnih aktivnosti i interakcija, a mogu da se koriste i u kombinaciji sa nekim drugim indikatorima. Merenje ideja, kao glavnih produkta nauke, nije jednostavno, a i svaki pokazatelj ima svoje prednosti i mane koje je potrebno uzeti u obzir. Prvi bibliometrijski pokazatelj - broj publikovanih radova - odražava rezultate naučnog rada. Broj publikovanih radova pruža inicijalnu i pojednostavljenu meru količine rada koju je istraživač, odeljenje, institutcija, nacionalni ili međunarodni naučni tim, zemlja proizvela. Citiranost, kao jedan od najpoznatijih bibliometrijskih indikatora, može se posmatrati kao mera uticaja citiranog članka i odraz njegove korisnosti koju naučno društvo prepoznaje. Broj koautorskih radova pokazatelj je naučno-istraživačke saradnje ostvarene na individualnom ili institucionalnom, kao i nacionalnom ili međunarodnom nivou. Sa razvojem različitih mrežnih informacionih tehnologija pojavile su se i visoko razvijene kvantitativne i kvalitativne bibliometrijske metode.

Broj citata koji je dobio neki rad još uvek predstavlja osnovni pokazatelj, često povezan sa izvanrednim naučno-istraživačkim odlikama. Uporedo sa porastom interesovanja za vrednovanje naučno-istraživačkih rezultata raste i broj bibliometrijskih studija koje se bave visoko citiranim radovima različitih naučnih disciplina [2-5]. Pojam visoko citiranih članaka opisivan je u radovima različitih naučnih oblasti i imenovan na više načina, poput najcitiraniji radovi, klasici, vrhunski citirani radovi itd. Naučno-istraživački radovi, okarakterisani kao klasici ili vrhunski citirani radovi, bili su predmet istraživanja više disciplina, uključujući karcinom usne duplje $[6,7,8]$, maksilofacijalnu hirurgiju $[9,10]$, stomatološku implantologiju $[3,11$, 12], endodonciju [13], ortodonciju [14, 15], ili parodontologiju [16]. U većini sprovedenih bibliometrijskih studija analizirani su najcitiraniji članci preuzeti iz baze Web of Science Clarivate Analytics, koja je široko prepoznata kao najsveobuhvatniji izvor najuticajnijih časopisa širom sveta.

Srpske stomatološke akademske, istraživačke i kliničke ustanove imaju dugu i bogatu tradiciju objavljivanja naučno-istraživačkih rezultata. Identifikacija članaka koji su izvršili najveći uticaj, mereno brojem dobijenih citata, može da bude polazna tačka za opis srpske stomatološke naučne komunikacije i njenih istraživanja svetskog ranga. Svrha ove studije je bila da se, koristeći ustanovljeni metod evaluativne bibliometrije, identifikuju najčešće citirani članci koje su objavili autori povezani sa srpskim stomatološkim institucijama i odeljenjima, kao i da se analiziraju njihove karakteristike radi opisa saradnje ostvarene na individualnom i institucionalnom, ali i na nacionalnom $\mathrm{i}$ internacionalnom nivou. Ovom analizom obuhvaćeni su naučni radovi objavljeni u periodu od 1996. do 2008. godine, prikupljeni putem baze Web of Science, uključujući broj dobijenih citata, časopise u kojima su objavljeni, pripadajuće Web of Science kategorije, zemlje, ustanove, podatke o autorstvima, ključne reči koje su autori dodelili i generički dodeljene ključne reči u okviru Web of Science KeyWords Plus.

\section{MATERIJAL I METODE RADA}

Korpus najcitiranijih radova istraživača povezanih sa srpskim stomatološkim ustanovama i odeljenjima, dobijen iz baze Web of Science Clarivate Analytics, upotrebljen je za dalju analizu. Pretraživanje je sprovedeno uz pomoć Web of Science Core Collection 
citatnih indeksa, koji se sastoje od sledećeg: Science Citation Index Expanded (SCI-EXPANDED), Social Sciences Citation Index (SSCI), Arts \& Humanities Citation Index (A\&HCI), Conference Proceedings Citation Index-Science (CPCI-S), Conference Proceedings Citation Index-Social Science \& Humanities (CPCI-SSH) i Emerging Sources Citation Index (ESCI). Citatna baza Web of Science ne pokriva većinu održanih stomatoloških simpozijuma, osim onih čiji su izlagani radovi objavljeni u specijalnim brojevima određenog časopisa, referisanog u bazi Web of Science. Sledeći princip pretrage bio je osnova za dalju analizu:

ADDRESS: (( $\operatorname{srb}^{\star}$ OR serb $\left.{ }^{\star}\right)$ SAME $\left(\right.$ dent $^{\star}$ OR stom* OR maxill $^{\star}$ OR oral OR prosthod ${ }^{\star}$ OR orthodon ${ }^{\star}$ OR endod $^{\star}$ OR periodon $\left.^{\star}\right)$ )

Indexes $=$ SCI-EXPANDED, SSCI, A\&HCI, CPCI-S, CPCISSH, ESCI

Timespan $=1996-2018$

Svi radovi dobijeni ovom pretragom uključeni su u analizu bez ograničenja vezanih za sam tip rada. Na samom početku dobijen je 1.451 rad koji su objavili autori povezani sa srpskim stomatološkim ustanovama i odeljenjima. Radovi su sortirani uz pomoć opcije times cited u opadajućem nizu, od najviše ka najmanje citiranim radovima (svi radovi su rangirani po broju citata dobijenih u bazi Web of Science).

Nakon toga izdvojeno je 100 najcitiranijih radova objavljenih u periodu od 1996. do 2018. godine. Imajući u vidu da su radovi rangirani kao 101.i 102. imali isti broj citata kao i poslednja dva izdvojena rada, i oni su uključeni u ovu analizu. Od 1.451 rada, 462 rada nikada nisu bila citirana u bazi Web of Science, dok je 989 radova bilo citirano bar jednom. Za 102 najcitiranija rada generisan je dokument u RIS formatu, koji je uvezen u BibExcel [18] radi sprovođenja bibliometrijske analize. BibExcel je program napravljen tako da pomaže pri analizi bibliometrijskih podataka, ili bilo kakvih tekstualnih podataka formatiranih na sličan način. Ovaj program omogućava rad sa velikim kolekcijama podataka i kompatibilan je sa mnogim drugim programima koji se koriste za analizu umreženih podataka. Za analizu bibliometrijskih podataka i njihovu vizualizaciju korišćen je VOSviewer [19].

Za svaki članak su zabeležene i uključene u analizu sledeće promenljive: podaci o autorima (prvi autor, koautor), naziv članka, tip rada, citirana literatura, zemlja porekla i naziv institucije, ključne reči, KeyWords Plus, broj dobijenih citata (Web of Science Core Collection), naziv časopisa i godina publikovanja, Web of Science kategorija i oblast istraživanja.

Svaki rad je analiziran uzimajući u obzir institucije i zemlje svih autora rada, a ne samo prvog autora ili autora određenog za prepisku. Zapisi su pregledani i usaglašavani radi ujednačavanja termina i uklanjanja tipografskih grešaka, kao i grešaka nastalih prilikom transkripcije ili indeksiranja. Podaci koji su usaglašeni su podaci o autoru, instituciji, zemlji porekla i nazivu časopisa. Postojalo je nekoliko različitih varijanti imena jednog autora ili institucije koje je trebalo proveriti i ujednačiti, kako na makronivou, tj. nivou univerziteta i istraživačkih centara, tako i na mikronivou, tj. nivou pojedinačnih odseka i istraživačkih organizacionih jedinica. Članci kojima je za zemlju porekla bila navedena Srbija i Crna Gora, budući da su objavljeni nakon 1996. godine, iznova su klasifikovani kao radovi iz Srbije. Kada je reč o časopisima, samo je jedan, zbog promene naslova časopisa, imao navedene različite varijante, koje je bilo potrebno ujednačiti.

\section{REZULTATI}

U Dodatku rada (dostupno onlajn), u opadajućem redosledu zasnovanom na broju dobijenih citata, prikazani su detaljni podaci o 102 najčešće citirana rada povezana sa srpskim stomatološkim institucijama i odsecima. Podjednako citirani članci sortirani su hronološki u skladu sa njihovim datumom objavljivanja (npr. članci sa oznakama Article ID 11 i 12 u Dodatku rada).

Skup posmatranih članaka citiran je ukupno 4.598 puta 1996-2018. godine. U ovoj studiji utvrđena srednja vrednost dobijenih citata po članku iznosi 45,08. Najuobičajeniji tipovi radova bili su radovi objavljeni u časopisima između 1997. i 2016, uključujući originalne naučne $(\mathrm{n}=92)$ i pregledne radove $(\mathrm{n}=8)$, kao i dva rada izlagana na kongresima (Tabela 1$)$.

Distribucija najcitiranijih radova u odnosu na godinu publikovanja i ukupan broj dobijenih citata prikazani su na Grafikonu 1. Broj dobijenih citata posmatranih članaka nalazi se u rangu između 23 (Article ID 99-102) i 226 (najcitiraniji rad). Pet najcitiranijih članaka citirano je više od 100 puta, pri čemu je onaj najčešće navođen (c = 226) pregledni rad objavljen 2008. godine. Od ukupnog broja posmatranih radova, gotovo $52 \%$ se pojavilo u periodu 2006-2010, dok je 35,3\% i 10,8\% publikovano u periodu 2011-2016, odnosno 2000-2005. Veoma mali broj radova $(n=2)$ datira iz perioda 1996-1999. Godine 2007. objavljeno je najviše $(n=18)$ najcitiranijih radova, a slede je 2009, 2010 i 2012. godina ( $n=11)$. Osim toga, pet najcitiranijih članaka objavljeno je 2002, 2007, 2008 i 2010. godine.

Ukupan broj citata koje su dobila ova 102 najcitiranija rada u odnosu na njihovu starost prikazan je na Grafikonu 2. Najveći ukupan broj citata $(c=822)$ dobilo je 18 radova publikovanih pre 11 godina. $S$ druge strane, radovi stari osam godina dobili su ukupno 638 citata, što predstavlja najveći broj dobijenih citata po godini $(\mu=79,8)$. Najcitiraniji originalni naučni rad je: Jensen SB, Pedersen AML, Vissink A, Andersen E, Brown CG, Davies AN, et al. A systematic review of salivary gland hypofunction and xerostomia induced by cancer therapies: management strategies and economic impact. Supportive Care in Cancer. 2010; 18(8):1061-79. (Article ID 1); dok je najcitiraniji pregledni rad: Radovic I, Monticelli F, Goracci C, Vulicevic ZR, Ferrari M. Selfadhesive resin cements: A literature review. Journal of Adhesive Dentistry. 2008; 10(4):251-8. (Article ID 2).

\section{Časopisi}

Najuticajnija 102 rada stomatoloških institucija ili odseka objavljena su u 60 naučnih časopisa. Časopisi čiji je doprinos najveći u smislu broja objavljenih radova su Journal of Periodontology, Dental Materials i Clinical Oral Implants Research $(\mathrm{n}=15)$, zatim Journal of Clinical Periodontology, Journal of Endodontics i Oral Surgery, Oral Medicine, Oral Pathology, Oral Radiology (n = 12). Od ukupnog broja časopisa, u 39 (65\%) naslova objavljen je samo po jedan rad, dok je u oko 25\% časopisa objavljeno po dva ili tri rada. U Tabeli 2 prikazani su najuticajniji časopisi prema broju dobijenih citata, kao i njihov rang na kvartalnim listama, zasnovan na podacima o impakt faktoru iz Journal Citation Reports liste iz 2017. godine. Iako je većina najcitiranijih radova objavljena u visoko rangiranim časopisima, članak koji se ističe po broju dobijenih citata objavljen je u časopisu American Journal of Dentistry, koji se na osnovu distribucije impakt 
faktora predmetne kategorije kojoj pripada nalazi u najnižem kvartalnom rangu. Časopisi u kojima su objavljeni ovi najcitiraniji radovi razvrstani u 40 predmetnih kategorija Web of Science. Nešto više od polovine ovih časopisa pripada kategoriji stomatologija, oralna hirurgija i medicina (eng. Dentistry, Oral Surgery \& Medicine), dok ostalim kategorijama (npr. Materials Science, Biomaterials; Engineering, Biomedical; Surgery) pripada $12 \%$ ili manje naslova.

\section{Autori, institucije i zemlje}

Učestalost pojavljivanja svih autora detaljno je zabeležena. Zabeleženo je ukupno 446 autora, odgovornih za 726 autorstava, povezanih sa 149 institucija iz 41 zemlje. Broj autora u najcitiranijim radovima kreće se od dva do 32, dok je utvrđeni prosečan broj autora po radu sedam. S obzirom na to da su 2015. godine sprovedene tri velike studije (Article ID 23, 43, 54), koje u proseku imaju 22,8 autora po radu, prosečan broj autora po radu povećao se sa 2,5 u 1990-im na 7,5 u 2000-im (Grafikon 3). Osim ovih objavljenih 2015. godine, postoje još tri studije sa po više od 20 koautora (Article ID 2, 5, 32). Veliki deo radova $(40,2 \%)$ ima više od po šest autora, dok 22 članka imaju po šest autora. Od 102 najčešće citirana rada, njih pet, osam, 10 i 16 imaju po dva, odnosno tri, četiri i pet autora.

Utvrđeno je da su 72 istraživača doprineli izradi ovih najcitiranijih radova kao prvi autori. U Tabeli 3 prikazani su najproduktivniji autori prema broju objavljenih radova. Kao što je navedeno, Ferrari je prvi na listi sa 13 objavljenih radova, zatim Radović, Leković, Kenney, Goracci, Camargo i Weinlaender, svako sa više od po sedam objavljenih članaka. Treba napomenuti da su ovi autori u velikom broju radova koautori. Na primer, Ferrari, Radović i Goracci su koautori u 12 radova u proteklih 11 godina. Osim toga, druga grupa autora, tj. Leković, Kenney, Camargo i Weinlaender koautori su u sedam radova.

Od ukupnog broja autora, 238 autora je iz Srbije, dok je njih 211 povezano sa stranim institucijama. U Tabeli 4 prikazano je 20 autora iz Srbije, čiji je doprinos, pre svega kao prvih autora, najveći. Ignjatović je istraživač sa najvećim brojem članaka u kojima je on prvi autor, zatim Radović, Leković, Čolić i Marković.

$\mathrm{Na}$ osnovu adresa autora navedenih u radovima, 69 članaka je plod međunarodne saradnje, dok su preostala 33 rada rezultat institucija iz Srbije. Ukupno 108 autora je iz srpskih stomatoloških institucija ili odseka, dok je ostalih 130 iz drugih srpskih institucija. Učešće drugih zemalja u najcitiranijim radovima autora iz srpskih stomatoloških institucija ili odseka prikazano je na Slici 1, prema broju koautorstava. Od ukupno 41 zemlje, prvi autori radova potiču iz samo 13 (Austrija, Kanada, Danska, Engleska, Nemačka, Italija, Holandija, Škotska, Srbija, Španija, Švedska, Švajcarska i SAD). Osim Srbije, i druge zemlje čiji je doprinos visok, zastupljene su sa po više od šest nacionalnih institucija. Najveći broj institucija $(n=23)$ potiče iz SAD, zatim Engleske $(n=10)$, Italije $(n=9)$, Nemačke $(n=8)$, kao i Kanade i Španije $(n=6)$. Dve najproduktivnije institucije su Univerzitet u Beogradu i Vojnomedicinska akademija (Tabela 5). Ove dve najproduktivnije institucije slede Univerzitet u Sijeni, Univerzitet u Nišu, Univerzitet Kalifornije (Los Anđeles) i drugi. Od ukupnog broja institucija, 102 najproduktivnije prikazane su na Slici 2.

\section{Ključne reči}

U 102 najčešće citirana rada utvrđeno je ukupno 176 upotrebljenih ključnih reči. Na Slici 3 prikazane su najčešće korišćene ključne reči autora $(\mathrm{n}=77)$ i KeyWords Plus $(\mathrm{n}=99)$, prema tome koliko puta su korišćene u analiziranim radovima. Prikazane su najčešće upotrebljavane ključne reči, sa vezama koje postoje među njima, dok su različiti klasteri obeleženi različitim bojama.

\section{DISKUSIJA}

Cilj ove bibliometrijske studije je identifikovanje najčešće citiranih radova povezanih sa srpskim stomatološkim institucijama i odeljenjima i njihovih osnovnih karakteristika, radi prikazivanja srpskog naučnog napretka postignutog na polju stomatologije, ali i pravaca stomatoloških istraživanja. Iako je proučavanje citiranosti široko rasprostranjeno [3-8, 10, 12-20], ova vrednost ne bi mogla da se posmatra kao apsolutni pokazatelj naučnog rada, ali može da pruži objektivan i merljiv uvid u to koliko je neki članak ostvario uticaj na naučnu zajednicu odgovarajuće oblasti [21,22]. Najcitiranija 102 rada, povezana sa srpskim stomatološkim institucijama ili odeljenjima, citirana su između 23 i 261 puta. Pet najčešće citiranih radova navođeni su više od 100 puta $i$, shodno dosadašnjim sprovedenim studijama u ovoj oblasti, oni se mogu posmatrati kao citatni klasici [23]. Ipak, treba napomenuti da je broj dobijenih citata značajno manji u odnosu na citatne stope klasika većih medicinskih oblasti $[24,25]$.

Gotovo svi radovi obuhvaćeni ovom studijom objavljeni su u časopisima koji zauzimaju najviše ili visoke pozicije u svojim predmetnim kategorijama. Citiranost radova nekog pojedinca u velikoj meri zavisi i od broja njegovih publikovanih radova, ali značajno je uvećava i rad u okviru velikih istraživačkih timova i koautorskih grupa [26]. Saradnja je značajan faktor u naučnoj produktivnosti, ali u zavisnosti od discipline [27]. Zajednički rad je uobičajen za većinu naučnih disciplina, pa tako i za medicinu. Prosečan broj autora po radu utvrđen u ovoj studiji je sedam, što je malo više od prosečnog broja autora po radu prema ostalim studijama iz oblasti stomatologije [20]. Budući da je u ispitivanje uključeno i šest velikih studija, sa po više od 22 autora po radu, prosečan broj autora po radu porastao je sa 2,5 u 1990-im na 7,5 u 2000-im. Identifikovane koautorske mreže ključne su za utvrđivanje distribucije institucija i zemalja. Većina članaka rezultat je saradnje sa istraživačima iz institucija SAD, kao i Evrope, tj. Italije, Španije i Finske.

Ključne reči koje su autori izabrali pružaju prihvatljivu sliku o tome šta je tema članka, dok KeyWords Plus, generisane nezavisno od ključnih reči autora, opisuju njegov sadržaj sa većom dubinom i raznolikošću [28]. Radi prevazilaženja ograničenja koja mogu biti rezultat upotrebe relativno malog uzorka ključnih reči autora, za analizu i prikaz tema članaka korišćene su i ključne reči KeyWords Plus.

Sa metodološke tačke gledišta, postoje određena ograničenja sprovedene studije. Za utvrđivanje najčešće citiranih radova povezanih sa srpskim stomatološkim institucijama i odeljenjima korišćena je samo baza Web of Science, dok ostale baze nisu bile obuhvaćene. Stoga su možda propušteni neki važni članci, objavljeni u časopisima koji nisu uključeni u Web of Science. 
Osim toga, autocitati nisu bili isključeni iz ukupnog broja dobijenih citata članaka, što u određenoj meri može da poveća stopu citiranosti. Pored toga, prilikom analize autorstava svim autorima nekog rada priznat je kompletan doprinos, bez obzira na ukupan broj koautora u radu. Na samom kraju, nije sprovedena sadržinska analiza ovih uticajnih članaka, uključujući najčešće područje ispitivanja i dizajn studije, kao i nivo dokaza.

Uprkos ovim očiglednim ograničenjima, podaci predstavljeni u ovom radu ipak pružaju značajan uvid u dostignuća i nove pravce srpskih stomatoloških istraživanja tokom prošlih decenija. Prema saznanjima autora, ovo je prvi izveštaj o najčešće citiranim radovima povezanim sa srpskim stomatološkim institucijama ili odeljenjima.

\section{ZAKLJUČAK}

Ovaj rad se bavi analizom karakteristika 102 najčešće citirana članka, povezana sa srpskim stomatološkim institucijama ili odeljenjima 1996-2018. godine u okviru baze Web of Science. Sprovedena bibliometrijska analiza prikazuje porast prosečnog broja citiranosti ovih najcitiranijih članaka i ističe pravce srpskih stomatoloških naučno-istraživačkih radova. S obzirom na to da se broj citata neprekidno menja, rezultati predstavljeni u ovom radu daju prikaz ovog trenutka najuticajnijih članaka povezanih sa srpskim stomatološkim institucijama i odeljenjima.
Najčešće citirani radovi objavljeni su u 60 časopisa u periodu od 1997. do 2016. godine, sa prosečnim brojem dobijenih citata po radu od 45,08. Ove radove je napisalo 449 autora, odgovornih za 726 autorstava, povezanih sa 149 institucija iz 41 zemlje. Od ukupnog broja autora, 238 je bilo iz Srbije, dok je 211 bilo povezano sa stranim institucijama. Srpski autori koji su najviše doprineli u pogledu broja publikovanih radova su Radović Ivana i Leković Vojislav, zatim Milašin Jelena, Čolić Miodrag i Ignjatović Nenad. Najproduktivnije institucije bile su Univerzitet u Beogradu i Vojnomedicinska akademija iz Srbije, dok su kod stranih institucija najveći doprinos dale prevashodno one koje potiču iz SAD, Engleske, Italije, Nemačke, Kanade i Španije. Sarađivanje više institucija, kao i međunarodna saradnja, pospešuju sprovođenje visoko kvalitetnih istraživanja. Osim kategorija stomatologija, oralna hirurgija i medicina, najviše citirani članci su objavljivani u časopisima koji pripadaju i drugim raznovrsnim predmetnim kategorijama Web of Science, na taj način otkrivajući multidisciplinarnu prirodu istraživanja ispitivanih najcitiranijih članaka.

Radi sveobuhvatnijeg uvida u ovu literaturu bilo bi veoma korisno sprovesti precizniju analizu sadržaja i klasifikaciju istraživanih najcitiranijih radova povezanih sa srpskim stomatološkim institucijama i odeljenjima. Poželjna su buduća istraživanja koja će se baviti ovim pitanjima kako bi se novim istraživačima omogućilo upoznavanje sa pristupima i metodama koiršćenim $\mathrm{u}$ istraživanjima najcitiranijih radova, ali i pomoglo da uoče aktuelne uticajne teme. 